\title{
Podróż wizytacyjna archidiakona Andrzeja Albinowskiego w archidiakonacie pomorskim w 1686 i 1687 r.
}

\section{Tomasz Nowicki}

\section{Wprowadzenie}

Staropolskie wizytacje kanoniczne to źródła historyczne umożliwiające podjęcie wszechstronnych badań naukowych. Znaczenie i możliwości różnego ich wykorzystania w studiach historycznych opisywał już pół wieku temu Stanisław Litak ${ }^{1}$. Późniejsi badacze wskazywali na korzyści w wykorzystaniu wizytacji do badań nad duchowieństwem ${ }^{2}$ czy historią kultury materialnej ${ }^{3}$. Bez wątpienia bogaty materiał wizytacyjny pozwala także na wykorzystanie informacji zapisanych w wizytacjach do studiów geograficzno-historycznych. Przede wszystkim źródła tego typu umożliwiają badania nad siecią parafialną, osadnictwem czy topografią. Z kolei cykl przeprowadzania wizytacji, polegający na odwiedzaniu poszczególnych świątyń i miejscowości, może dać dobry materiał do studiów nad przemieszczaniem się wizytatorów i delegatów biskupich. Prezentowany artykuł ma właśnie na celu przedstawienie trasy podróży archidiakona Andrzeja Albinowskiego, którego biskup włocławski Bonawentura Madaliński wyznaczył do przeprowadzenia wizytacji świątyń leżących w archidiakonacie pomorskim.

Nie ulega wątpliwości, że podejmując się tego zadania, wizytator musiał wcześniej przyjąć plan, zgodnie z którym przybywał do poszczególnych parafii odwiedzanego okręgu. Chcąc, by wizytacja była przeprowadzona sprawnie

1 S. Litak, Akta wizytacyjne parafii z XVI-XVIII wieku jako źródło historyczne, ,Zeszyty Naukowe KUL”, 5 (3), 1962, s. 41-58.

2 S. Olczak, Wizytacje jako źródto do badań nad klerem parafialnym, „Summarium", 8, 1979, s. 253-258; tenże, Źródła kościelne z końca XVI i pierwszej połowy XVII wieku do badań nad duchowieństwem, „Przegląd Tomistyczny", 2, 1986, s. 275-291.

3 D. Gtówka, Akta wizytacji kościelnych z XVII-XVIII wieku jako źródto do historii kultury materialnej: gospodarstwo wiejskie w dobrach parafialnych w archidiakonacie warszawskim, w: Szkice z dziejów materialnego bytowania spoteczeństwa polskiego, red. M. Dembińska, Wrocław 1989, s. 233-254. i efektywnie, bez niepotrzebnej straty czasu, należało tak przygotować etapy podróży, by nie nadkładać przebytej drogi i płynnie przemieszczać się między pobliskimi kościołami. Takie podejście generuje pytania o wybór kolejności, w jakiej należało odwiedzać świątynie. Po pierwsze, czy decydowała o niej np. ich przynależność dekanalna, czy też raczej pragmatyzm samego wizytatora wybierającego najbliżej położone ośrodki (niekoniecznie znajdujące się w tych samych dekanatach)? Po drugie, jaki dystans potrafił on pokonać w określonym czasie, czyli inaczej mówiąc, jak szybko był w stanie się przemieszczać?

Warto jeszcze na wstępie zaznaczyć, że na podstawie zapisów wizytacyjnych nie da się precyzyjnie odtworzyć $\mathrm{w}$ terenie tras przemieszczania się delegatów biskupich. Po pierwsze bowiem, trudno dokładnie określić sieć lokalnych dróg sprzed kilkuset lat, a po drugie, w wizytacjach brakuje przecież opisów trasy, po której przemieszczał się wizytator $\mathrm{i}$ jego świta. Czasami zresztą analiza datacji każe zadać pytanie, czy w ogóle był w danej parafii we wskazanym w źródle dniu. Stąd też odległości, które posłużyły do prezentowanych w niniejszym artykule analiz, zostały obliczone w linii prostej. Ustalając je, brano pod uwagę lokalizację świątyni w danej miejscowości.

Wyjaśnienia wymaga również zakres terytorium, którego dotyczy niniejszy artykuł. Oczywiście jego zasięg zdeterminowany został samym źródłem i objął ten fragment diecezji włocławskiej, który zawierał się w części dawnego województwa pomorskiego i nosił w nomenklaturze kościelnej nazwę archidiakonatu pomorskiego. Granice tej jednostki w okresie przedrozbiorowym nie ulegały zasadniczym zmianom. Na północy opierały się o Morze Bałtyckie, począwszy od ujścia Łeby na za- 
chodzie, do Motławy na wschodzie. Granica wschodnia tego terytorium przebiegała na Wiśle, w całym jej dolnym biegu i dopiero niemal pod Fordonem skręcała na północny wschód, osiągając koło miejscowości parafialnej Serock Brdę. Potem, idąc w górę rzeki, docierała do jej źródeł, po czym skręcała wyraźnie na północ, by objąć całe starostwo bytowskie. Następnie, pokrywając się z granicą państwową, dochodziła do starostwa lęborskiego, by z biegiem rzeki Łeby osiągnąć wybrzeże Bałtyku.

Terytoria, z którymi graniczył archidiakonat pomorski, to: od wschodu archidiakonat malborski diecezji chełmińskiej, dalej na południe, w okolicach Kwidzynia Prusy Książęce, potem archidiakonat chełmiński. Na południu leżał archidiakonat kruszwicki, należący do tej samej diecezji włocławskiej, zaś na południowym zachodzie - archidiakonat kamieński archidiecezji gnieźnieńskiej. Od zachodu sąsiadem archidiakonatu pomorskiego było Pomorze Zachodnie, należące do Brandenburgii.

Obszar badanego archidiakonatu obejmował $11659 \mathrm{~km}^{2}$, co stanowiło ponad $60 \%$ terytorium ówczesnej diecezji włocławskiej. W jego skład wchodziło 10 dekanatów, a mianowicie, w kolejności wizytowania: starogardzki, mirachowski, bytowski, lęborski, pucki, gdański, tczewski, gniewski, nowski i świecki. Na pocz. XVIII w. okręg ten liczył 90 kościołów parafialnych. Sieć tę uzupełniały świątynie pomocnicze (filialne, szpitalne i kaplice publiczne). W omawianym czasie istniało tam ok. 55 tego typu obiektów sakralnych ${ }^{4}$. Z pewnością kilkanaście lat wcześniej, kiedy Andrzej Albinowski wizytował archidiakonat z mandatu biskupa Bonawentury Madalińskiego, liczba świątyń była podobna.

\footnotetext{
4 Zob. T. Nowicki, Ministri ecclesiae. Stużba kościelna i witrycy w diecezji włocławskiej w XVIII wieku, Lublin 2011, s. 59. Zbliżone, aczkolwiek nieco zaniżone dane we wcześniejszym opracowaniu tegoż autora: Liczba i sieć świątyń w archidiakonacie pomorskim w latach 1583-1781, „Studia Pelplińskie”, 28, 1999, s. 180. Z kolei z ustaleń Stanisława Litaka wynika, że ok. 1772 r. w badanym archidiakonacie było 86 parafii i 67 filii. S. Litak, Kościót taciński w Rzeczypospolitej około 1772 roku, Lublin 1996, s. 124; tenże, Atlas Kościoła łacińskiego w Rzeczypospolitej Obojga Narodów w XVIII wieku, Lublin 2006, s. 91. Inne, ale porównywalne liczby zaprezentował Bogumił Szady, widząc na terenie archidiakonatu pomorskiego w 2. poł. XVIII w. 83 kościoły
}

Zakres chronologiczny zdeterminowany został wykorzystaną w artykule podstawą źródłową, czyli wizytacją biskupa Bonawentury Madalińskiego przeprowadzoną przez archidiakona pomorskiego Andrzeja Albinowskiego jesienią 1686 i wiosną 1687 r. W Archiwum Diecezjalnym w Pelplinie znajdują się jej dwa identyczne w treści egzemplarze. Pierwszy, zewidencjonowany pod sygnaturą G20a, nosi tytuł Visitatio Archidiaconatus Pomeraniae sub felicissimis auspiciis Illustrissimi et Reverendissimi Domini D. Bonaventurae de Niedielsko Madaliński Dei et Apostolicae Sedis gratia Episcopi Vladislaviensis et Pomeraniae a Perillustri et Admodum Reverendo Domino Andrea Albinowski Archidiacono Pomeraniae, Cantore Premisliensi, Praeposito Volboriensi Anno 1686 et 1687 peracta (dalej: ADPel, G20a) ${ }^{6}$. Drugi egzemplarz, oznaczony sygnaturą G20b, zatytułowano Visitatio Archidiaconatus Pomeraniae sub felicissimis auspiciis Ilustrissimi et Reverendissimi Domini Bonaventurae de Niedzielsko Madalinski, Dei et Apostolicae Sedis Gratia Episcopi Vladislaviensis et Pomeraniae, a Perillustri et Admodum Reverendo Domino Andrea Albinowski Archidiacono Pomeraniae, Cantore Praemisliensi, Praeposito Volboriensi, Anno Domini 1686 et 1687 peracta (dalej: ADPel, G20b)7. Oba mają charakter czysto opisowy. Tekst i kolejność poszczególnych wpisów są identyczne. W obu księgach po kartach tytułowych zamieszczono list archidiakona Albinowskiego do duchowieństwa archidiakonatu informujący o rozpoczęciu wizytacji. Następnie wpisano pytania, według których zamierzano wizytować świątynie, zaś po nich znalazły się właściwe protokoły wizytacji parafii, począwszy od dekanatu starogardzkiego, a skończywszy na świeckim. Na końcu wpisano

gtówne i 68 pomocniczych. B. Szady, Geografia struktur religijnych i wyznaniowych w Koronie w II połowie XVIII wieku, Lublin 2010, s. 150. 5 Z danych źródłowych wynika, że wizytator odwiedził 136 miejscowości, w których znajdowały się świątynie lub miejsca po obiektach sakralnych. Por. T. Nowicki, Liczba i sieć, s. 177.

6 Szczegółowy opis księgi i jej zawartości zob. W. Kujawski, Repertorium ksiąg wizytacji kanonicznych biskupów kujawsko-pomorskich przechowywanych w Archiwum Diecezjalnym w Pelplinie, „Archiwa, Biblioteki i Muzea Kościelne", 84, 2005, s. 120-162.

7 Szczegótowy opis księgi i jej zawartości zob. W. Kujawski, Repertorium ksiag, s. 163-195. 
dekrety powizytacyjne. Obie księgi zamyka indeks zawartości, w którym podane są nazwy wizytowanych świątyń i strona, od której rozpoczyna się protokół wizytacyjny i dekret. Tylko z krótkiej notatki umieszczonej na rewersie strony tytułowej egzemplarza G20b wiadomo, że pierwotny jest G20a. Był on przechowywany w archiwum katedry włocławskiej. Spisany został jedną ręką, zapewne krótko po odbyciu wizytacji, najprawdopodobniej na podstawie roboczych brudnopisów powstałych w jej trakcie. Z kolei egzemplarz G20b przepisała jedna osoba na potrzeby konsystorza gdańskiego z polecenia sufragana pomorskiego Cypriana Kazimierza Wolickiego. Z podanych w tej notatce tytułów i stanowiska biskupa wynika, że powstał on po 24 lipca 1766 r., gdyż od tego dnia Wolicki zaczął tytułować się biskupem, ale przed jego śmiercią w dniu 16 maja 1775 r. ${ }^{8}$

Dzięki zachowaniu się dwóch egzemplarzy wizytacji łatwo było uzupełnić datację w przypadku jej braku w jednym z nich. W księdze G20a w kilkunastu przypadkach, najpewniej w trakcie zszywania księgi, przycięto marginesy, obcinając też informację o dacie dziennej, a zostawiając tylko miesiąc. Czynności te musiały być jednak wykonane jeszcze przed przepisaniem dubletu G20b, ponieważ w nim daty zostały określone precyzyjnie?.

Wybór wizytacji przeprowadzonej przez archidiakona Madalińskiego został podyktowany głównie możliwością uzyskania w miarę pełnych informacji określających daty dzienne protokołów wizytacyjnych. Opierając się na nich, można podjąć próbę odtwarzania drogi wizytatora w trakcie jego podróży. Dodatkowym elementem umożliwiającym przełożenie danych chronologicznych na mapę były daty

8 Dokładnie wspomniany zapis brzmi: „Haec Visitatio Anni 1687 ex suo Originali in Archivo Ecclesiae Cathedralis conservato fideliter pro commoditate Dioecesis Pomeraniae, et usu Consistorij Generalis Gedanensis copiata Cura Illustrissimi et Reverendissimi Domini Cypriani Casimiri de Komorze Wolicki Episcopi Sinopensis, Praepositi Ecclesiae Cathedralis Vladislaviensis Suffraganei Vicarij in Spiritualibus ac Parochi Gedanensis et per Pomeraniam Officialis Generalis". ADPel, G20b, k. Iv. Zob. S. Chodyński, Biskupi sufragani włocławscy, Włocławek 1906, s. 86-88.

9 Np. z egzemplarza G20a wiadomo jedynie, że w Pogódkach wizytacja odbyła się w listopadzie 1686 r. Zob. ADPel, G20a, k. 9v. Z kolei na dekretów. W przypadku ich datacji stosowano formułę informującą także o miejscu wystawienia dokumentu ${ }^{10}$.

\section{Interpretacja datacji}

Jak już wspomniano, daty w wizytacji biskupa Madalińskiego można znaleźć w dwóch różnych miejscach. Po pierwsze, zapisywano je na początku protokołu wizytacyjnego, na marginesach. Po drugie, pojawiają się także na końcu dekretów reformacyjnych. Niekiedy jednak próba ich porównania może rodzić poważne problemy interpretacyjne. Prawdopodobnie w niektórych etapach wizytacji mamy do czynienia z dwoma ciągami chronologiczno-geograficznymi, realizowanymi zapewne przez różne osoby. W dobrze uzasadniony i odwzorowany na mapie cykl chronologiczno-geograficzny układają się daty protokołów wizytacyjnych. Z kolei datacja dekretów pokazuje podobną marszrutę, choć nie zawsze jest ona zbieżna z podróżą odtworzona na podstawie dat protokołów. Jednakże w większości przypadków daty protokołów i dekretów uzupełniają się wzajemnie. Jak widać na prezentowanym niżej wykresie, protokół i dekret miały zwykle tę samą datę (53\%). Taka zbieżność może potwierdzać, że wizytator i najpewniej jego sekretarz byli danego dnia w tym samym miejscu. Wbrew pozorom nie ma również zastrzeżeń w sytuacji, kiedy dekret nosi datę późniejszą niż protokół (11\%). Naturalne jest przecież, że mógł zostać spisany nieco później. Prawdopodobnie delegaci biskupa przybywali do parafii po południu lub wieczorem poprzedniego dnia. Wtedy też spisywano protokól, natomiast dekret wystawiano rano, przed wyruszeniem w dalszą podróż ${ }^{11}$.

podstawie przepisanego w XVIII w. egzemplarza G20b można ustalić dokładną datę wizytacji parafii pogódkowskiej, która odbyła się 19 listopada 1686 r. Zob. ADPel, G20b, k6v.

10 Przykładowo w pierwszym dekrecie dla parafii starogardzkiej zapisano: „Datum in Starogard. 15 Novembris. Anno 1686”. ADPel, G20a, k. 138v; G20b, k. 84

11 Jedyne trudności interpretacyjne mogą dotyczyć Miłobądza, w którym protokół datowano zaraz po Wielkanocy, tj. na 1 kwietnia, zaś dekret wystawiono dopiero 9 kwietnia. ADPel, G20a, k. 69, 172v; G20b, k. 42, 106. W tym przypadku trudno wyjaśnić i uzgodnić daty z mapą. Wydaje się, że po świętach wizytator rozpoczął podróż właśnie 
W wielu przypadkach datacja dekretów i protokołów wyklucza możliwość, by główny wizytator, tj. archidiakon Albinowski, był tego samego dnia w kilku odległych geograficznie miejscach. W takim wypadku połączenie wszystkich występujących $\mathrm{w}$ protokołach i dekretach dat, przełożenie ich na mape

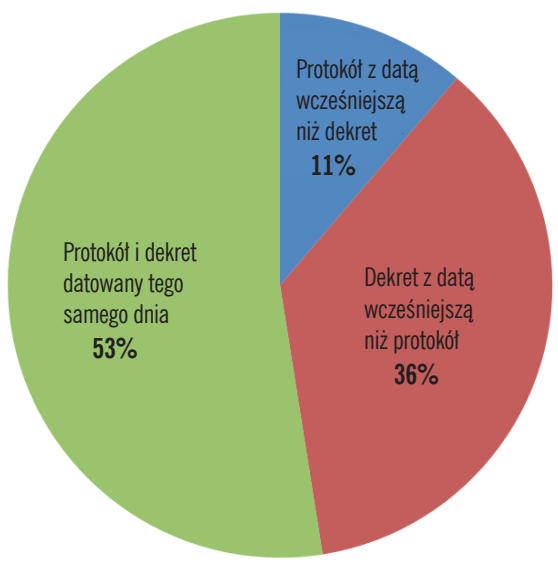

Wykres 1. Relacje dat protokotów i dekretów dla poszczególnych parafii

i ustalenie na tej podstawie marszruty staje się niekiedy całkowicie niemożliwe. Jak bowiem wyjaśnić fakt, że w 36\% parafii, dla których znamy datację protokołu oraz dekretu, data tego drugiego dokumentu jest wcześniejsza? Zasadniczo powinno być przecież odwrotnie,

w Miłobądzu. Tego samego dnia w drodze do Skarszew, które wizytowane były być może już wcześniej (tj. 27 marca, na co wskazywałaby data dekretu), Albinowski mógt być w Dalwinie i Demlinie. 2 kwietnia spisany został protokół dla parafii skarszewskiej, następnie 3 kwietnia archidiakon dotarł do Rekownicy, a potem zmierzał przez Niedamowo (3-4 kwietnia), Garczyn (4 kwietnia), Obozin (5 kwietnia) i Lubiszewo (6 kwietnia) do Tczewa (6-8 kwietnia) 9 kwietnia wystawił jeden dekret dla Miłobądza, Subków, Dalwina i Gorzędzieja. Czy był wówczas w leżącym na północ od Tczewa Miłobądzu, jak sugerowałoby miejsce wystawienia tego dekretu? Nie jest to niemożliwe, lecz byłoby nieracjonalne, bo tego samego dnia miał też zawitać do Gorzędzieja, Subków i Rajkowych, których odwiedzenie wymagało podróży w przeciwnym kierunku.

12 W $35 \%$ - jednodniowe, w $28 \%$ - dwudniowe, a w $21 \%$ - trzydniowe.

13 Dekret wydano w Klonówce z datą 13 listopada 1686 r. ADPel, G20a, k. 138v; G20b, k. 84. Z kolei data protokołu wskazywałaby, że wizytator przebywat tam 23 listopada. ADPel, G20a, k. 4; G20b, k. 2v. Ten przykład dowodzi jednak, że w zasadzie nie było fizycznie możliwe, by 23 listopada archidiakon Albinowski odwiedził Klonówkę, skoro tego samego dnia miał być również w oddalonym 0 ponad $51 \mathrm{~km}$ bo najpierw powinien zostać spisany protokół, a dopiero na jego podstawie - wydany dekret. Co ciekawe, w $84 \%$ tego typu przypadków opóźnienie protokołu w stosunku do dekretu było maksymalnie trzydniowe ${ }^{12}$. Jest jednak 5 parafii, w których protokół nosi datę o kilka dni późniejszą niż dekret. Są w tej grupie takie, od których Albinowski mógł rozpoczynać wizytację (Klonówka, Oksywie) ${ }^{13}$, ale też takie, w których być może zatrzymywał się na kilka dni ${ }^{14}$. Wyjaśnienie takich rozbieżności nie jest łatwe. Najprawdopodobniej początkowo czyniono jedynie notatki. Z kolei tego samego dnia, nazajutrz lub nawet kilka czy kilkanaście dni później pisano konspekt wizytacji. Czy robił to sam wizytator, czy też pojawiał się w parafii inny kapłan, być może jego sekretarz, który spisywał protokół wizytacjinie ma tutaj jednej odpowiedzi. W pewnym zakresie może to wyjaśnić ustalenie $\mathrm{w}$ ciągu chronologicznym każdej daty protokołu i dekretu. Szczegółowo kwestie te uwzględniają zestawienia w tabelach.

$\mathrm{Na}$ podstawie dat protokołów i dekretów $\mathrm{z}$ jesiennego etapu wizytacji można w miarę dokładnie wyznaczyć przyjęty plan podróży. Widać drobne rozbieżności, lecz nie ma tutaj przypadków (poza wizytowaną zapewne 13 grudnia Klonówką), by dekrety były pisane wcześniej niż protokoły. Wizytator prawdopodobnie odwiedził wszystkie świątynie,

w linii prostej Wielu, na co wskazuje datacja protokołu i dekretu. Tamże, G20a, k. 16, 149v; G20b, k. 9, 89v. Jeśli w obu datacjach nie ma błędu, to zapewne 23 listopada w Klonówce przebywat inny kapłan, którego archidiakon wysłał tam z dekretem. W przypadku parafii w Oksywiu dekret wystawiono 9 marca 1687 r. (ADPel, G20a, k. 162v; G20b, k. 99), lecz protokół nosi datę 19 marca (ADPel, G20a, k. 53v; G20b, k. 32v). Albo więc Albinowski rozpoczął wiosenną ture wizytacji właśnie w Oksywiu, a czystopis protokołu spisano później, albo też któraś z tych dat jest błędna.

14 Tak było najpewniej po wizycie w Matarni. Dekret datowano bowiem na 16 marca (ADPel, G20a, k. 164; G20b, k. 99v), ale protokół spisano 22 marca (ADPel, G20a, k. 56v; G20b, k. 34). Na taką krótką przerwę, zapewne w Gdańsku, wskazywać może datacja następnego dekretu na dzień 20 marca w Żukowie, odległym od Matarni 0 ok. $10 \mathrm{~km}$ w linii prostej (ADPel, G20a, k. 164v; G20b, k. 100) oraz 22 marca w Gdańsku, choć tutaj protokół spisano już 20 marca (ADPel, G20a, k. 56, 164v; G20b, 34v, 100). Z kolei parafie w Skarszewach, Szczodrowie i Wysinie były zapewne wizytowane przed Wielkanocą. Dekrety wystawiono 27 marca, ale protokoły zapisano z datami poświątecznymi (odpowiednio $2 \mathrm{i} 3$ kwietnia). ADPel, G20a, k. 70, 71v, 72, 169v, 170v; G20b, k. 42, 43, 43v, 103v, 104. 
Tab. 1. Datacje dekretów i protokołów w wizytacji dekanatów starogardzkiego, mirachowskiego, bytowskiego i lęborskiego z $1686 \mathrm{r}$.

\begin{tabular}{|c|c|c|}
\hline Data & Dekret & Protokót/Uwagi \\
\hline 13 listopada & Klonówka & $\begin{array}{l}\text { [Klonówka?] } \\
\text { Protokół spisany } 23 \text { listopada, co może być błędem. Jeśli jego data jest pra- } \\
\text { widłowa, to } 23 \text { listopada w Klonówce mógł się pojawić kapłan wydelegowany } \\
\text { przez wizytatora, który tego dnia był w oddalonym o ponad } 70 \text { km Wielu }\end{array}$ \\
\hline 15 listopada & Starogard & Starogard \\
\hline 16 listopada & Bobowo & $\begin{array}{l}\text { Kokoszkowy } \\
\text { Nowa Wieś } \\
\text { Jabłowo }\end{array}$ \\
\hline 17 listopada & - & $\begin{array}{l}\text { Dąbrówka } \\
\text { Bobowo }\end{array}$ \\
\hline 18 listopada & $\begin{array}{l}\text { Lubichowo } \\
\text { Zblewo } \\
\text { Pinczyn }\end{array}$ & $\begin{array}{l}\text { Lubichowo } \\
\text { Zblewo } \\
\text { Pinczyn }\end{array}$ \\
\hline 19 listopada & $\begin{array}{c}\text { Pogódki } \\
\text { Stara Kiszewa }\end{array}$ & $\begin{array}{c}\text { Pogódki } \\
\text { Stara Kiszewa } \\
\text { Stare Polaszki }\end{array}$ \\
\hline 21 listopada & Czersk & Czersk \\
\hline 22 listopada & - & Łąg \\
\hline 23 listopada & Wiele & $\begin{array}{c}\text { Wiele } \\
23 \text { listopada miano spisać także protokół dla Klonówki (zob. } 13 \text { listopada) }\end{array}$ \\
\hline 24 listopada & Brusy & Brusy \\
\hline 25 listopada & - & Leśno \\
\hline 26 listopada & $\begin{array}{l}\text { Lipusz } \\
\text { Kościerzyna }\end{array}$ & $\begin{array}{l}\text { Lipusz } \\
\text { Kościerzyna }\end{array}$ \\
\hline 28 listopada & - & Stężyca \\
\hline 30 listopada & Sulęczyno & Sulęczyno \\
\hline 1 grudnia & Parchowo & Parchowo \\
\hline 2 grudnia & - & Ugoszcz \\
\hline 3 grudnia & $\begin{array}{l}\text { Niezabyszewo } \\
\text { Tuchomie }\end{array}$ & $\begin{array}{c}\text { Niezabyszewo } \\
\text { Dąbrówka Bytowska } \\
\text { Borzytuchom }\end{array}$ \\
\hline 4 grudnia & - & $\begin{array}{l}\text { Tuchomie } \\
\text { Bytów }\end{array}$ \\
\hline 5 grudnia & Sierakowice & Sierakowice \\
\hline 6 grudnia & Chmielno & Chmielno \\
\hline 7 grudnia & Goręczyno & Goręczyno \\
\hline 8 grudnia & - & $\begin{array}{l}\text { Kiełpino } \\
\text { Kartuzy }\end{array}$ \\
\hline 9 grudnia & - & Sianowo \\
\hline 10 grudnia & Strzepcz & Strzepcz \\
\hline 12 grudnia & Lębork & Lębork \\
\hline 13 grudnia & - & $\begin{array}{l}\text { Nowa Wieś } \\
\text { Garczegorze } \\
\text { Białogarda } \\
\text { Łebień }\end{array}$ \\
\hline 14 grudnia & - & $\begin{array}{l}\text { Brzeźno Lęborskie } \\
\text { Rozłazino }\end{array}$ \\
\hline 15 grudnia & Luzino & Luzino \\
\hline
\end{tabular}

\section{II4 Studia Geohistorica • Nr 03. 2015}


dla których spisano protokoły. Oczywiście nie da się całkowicie wykluczyć, że w przypadku kościołów administrowanych przez plebanów z sąsiednich parafii, kościołów filialnych czy miejscowości, w których kiedyś były kaplice, opierał się tylko na opisach proboszczów.
Dużo więcej problemów stwarza wiosenny etap podróży. Można tutaj znaleźć dość częste przypadki, w których daty dekretów są wcześniejsze niż daty protokołów.

Odtworzenie wiosennego etapu podróży wizytatora jest dużo trudniejsze. Już na samym

Tab. 2. Datacje dekretów i protokotów w wizytacji dekanatów puckiego, gdańskiego, tczewskiego, gniewskiego, nowskiego i świeckiego z 1687 r.

\begin{tabular}{|c|c|c|c|}
\hline Data & Dekret & Protokół & Uwagi \\
\hline 9 marca & $\begin{array}{c}\text { Oksywie } \\
\text { Chwaszczyno }\end{array}$ & $\begin{array}{l}\text { Chwaszczyno } \\
\text { Wielki Kack }\end{array}$ & $\begin{array}{l}\text { Protokół dla Oksywia: zob. } 19 \text { marca. } \\
\text { Po protokole dla Chwaszczyna umieszczony jest } \\
\text { niedatowany protokół dla Wielkiego Kacka }\end{array}$ \\
\hline 10 marca & Kielno & Kielno & - \\
\hline 11 marca & Wejherowo & Szemud & Protokół dla Wejherowa: zob. 12 marca \\
\hline 12 marca & $\begin{array}{l}\text { Góra Pomorska } \\
\text { Żarnowiec }\end{array}$ & Wejherowo & $\begin{array}{l}\text { Protokół dla Góry Pomorskiej: zob. } 13 \text { marca. } \\
\text { Protokół dla Żarnowca: zob. } 14 \text { marca }\end{array}$ \\
\hline 13 marca & $\begin{array}{l}\text { Starzyno } \\
\text { Mechowo } \\
\text { Puck }\end{array}$ & $\begin{array}{l}\text { Bolszewo } \\
\text { Góra Pomorska } \\
\text { Kniewo } \\
\text { Lubocino }\end{array}$ & $\begin{array}{l}\text { Protokół dla Starzyna i Mechowa: zob. } 15 \text { marca. } \\
\text { Protokół dla Pucka: zob. } 16 \text { marca }\end{array}$ \\
\hline 14 marca & Strzelno & Żarnowiec & Protokół dla Strzelna: zob. 17 marca \\
\hline 15 marca & $\begin{array}{l}\text { Łebcz } \\
\text { Swarzewo } \\
\text { Reda } \\
\text { Rumia }\end{array}$ & $\begin{array}{l}\text { Starzyno } \\
\text { Mechowo }\end{array}$ & Protokół dla Łebcza i Swarzewa: zob. 17 marca \\
\hline 16 marca & Matarnia & Puck & $\begin{array}{l}\text { Wizytator zakończył wizytacje dekanatu puckiego } \\
\text { i prawdopodobnie udał się z Matarni do Żukowa, } \\
\text { skąd } 20 \text { marca rozpoczął wizytację gdańskiego. } \\
\text { Protokół dla Matarni: zob. } 22 \text { marca }\end{array}$ \\
\hline 17 marca & - & $\begin{array}{l}\text { Strzelno } \\
\text { Łebcz } \\
\text { Swarzewo }\end{array}$ & $\begin{array}{l}\text { Być może } 17 \text { i } 18 \text { marca sekretarz kończył wizytację } \\
\text { w wymienionych parafiach, sporządzając protokoły } \\
\text { na podstawie pozostawionych tutaj notatek wizyta- } \\
\text { tora, który odwiedził je wcześniej }\end{array}$ \\
\hline 18 marca & - & $\begin{array}{l}\text { Reda } \\
\text { Rumia } \\
\text { Chylonia }\end{array}$ & Zob. uwagi pod 17 marca \\
\hline 19 marca & - & Oksywie & $\begin{array}{l}\text { Datacja protokołu może być błędna i prawdopodobnie } \\
\text { powinno być } 9 \text { marca, czyli wówczas kiedy spisano } \\
\text { dekret. Analiza mapy nie wyklucza jednak, że se- } \\
\text { kretarz pojawił się tutaj ponownie } 19 \text { marca i spisał } \\
\text { czystopis protokołu }\end{array}$ \\
\hline 20 marca & Żukowo & Gdańsk & Protokół dla Żukowa: zob. 23 marca \\
\hline 22 marca & Gdańsk & Matarnia & - \\
\hline 23 marca & $\begin{array}{l}\text { Łeggowo } \\
\text { Ktodawa }\end{array}$ & Żukowo & $\begin{array}{l}\text { Protokół dla Łęgowa: zob. } 25 \text { marca. } \\
\text { Protokół dla Kłodawy: zob. } 26 \text { marca }\end{array}$ \\
\hline 24 marca & Trąbki Wielkie & $\begin{array}{c}\text { Pręgowo } \\
\text { Czapielsk } \\
\text { Mierzeszyn } \\
\text { Wielka Żuława }\end{array}$ & Protokół dla Trąbek: zob. 26 marca \\
\hline
\end{tabular}




\begin{tabular}{|c|c|c|c|}
\hline 25 marca & - & $\begin{array}{l}\text { Święty Wojciech } \\
\text { Łęgowo } \\
\text { Różyny }\end{array}$ & - \\
\hline 26 marca & - & $\begin{array}{c}\text { Kłodawa } \\
\text { Trąbki Wielkie }\end{array}$ & $\begin{array}{l}\text { Po protokole dla Kłodawy widnieje opis zniszczonej } \\
\text { kaplicy w Wojnowie, która znajduje się raczej na tra- } \\
\text { sie ze Świętego Wojciecha do Łęgowa. Być może } \\
\text { wcześniej wizytator przejeżdżał przez Wojnowo lub } \\
\text { też sporządził notatki na podstawie relacji plebana } \\
\text { kłodawskiego }\end{array}$ \\
\hline 27 marca & $\begin{array}{l}\text { Godziszewo } \\
\text { Giemlice } \\
\text { Skarszewy } \\
\text { Wysin }\end{array}$ & Godziszewo & $\begin{array}{l}\text { Protokół dla Giemlic: zob. } 28 \text { marca. } \\
\text { Protokół dla Skarszew: zob. } 2 \text { kwietnia. } \\
\text { Protokół dla Wysina: zob. } 3 \text { kwietnia }\end{array}$ \\
\hline 28 marca & - & Giemlice & - \\
\hline 1 kwietnia & - & $\begin{array}{l}\text { Miłobądz } \\
\text { Dalwin } \\
\text { Demlin }\end{array}$ & $\begin{array}{l}\text { Demlin został zapewne odwiedzony po drodze. } \\
\text { Nie było tu już wówczas kościoła, a tylko cmentarz }\end{array}$ \\
\hline 2 kwietnia & - & $\begin{array}{l}\text { Skarszewy } \\
\text { Szczodrowo }\end{array}$ & - \\
\hline 3 kwietnia & $\begin{array}{l}\text { Rekownica } \\
\text { Niedamowo }\end{array}$ & $\begin{array}{c}\text { Wysin } \\
\text { Rekownica }\end{array}$ & Protokół dla Niedamowa: zob. 4 kwietnia \\
\hline 4 kwietnia & Garczyn & $\begin{array}{l}\text { Niedamowo } \\
\text { Garczyn }\end{array}$ & - \\
\hline 5 kwietnia & Obozin & Obozin & - \\
\hline 6 kwietnia & Tczew & Lubiszewo & Protokół dla Tczewa: zob. 8 kwietnia \\
\hline 8 kwietnia & - & Tczew & - \\
\hline 9 kwietnia & Miłobądz & $\begin{array}{l}\text { Gorzędziej } \\
\text { Subkowy } \\
\text { Rajkowy }\end{array}$ & $\begin{array}{l}\text { Dekret dla Rajkowych wystawiono } 10 \text { kwietnia, ale wi- } \\
\text { zytator musiał tu być już wcześniej, skoro na } 9 \text { kwiet- } \\
\text { nia datowano protokół }\end{array}$ \\
\hline 10 kwietnia & $\begin{array}{l}\text { Rajkowy } \\
\text { Garc Wielki }\end{array}$ & Pelplin & $\begin{array}{l}10 \text { kwietnia na pewno wizytator był jeszcze w Rajko- } \\
\text { wych, bo wystawił tego dnia dekret powizytacyjny. } \\
\text { Tego samego dnia dotart jednak do Garca }\end{array}$ \\
\hline 11 kwietnia & $\begin{array}{l}\text { Lignowy } \\
\text { Szlacheckie }\end{array}$ & Garc Wielki & Protokół dla Lignowów Szlacheckich: zob. 12 kwietnia \\
\hline 12 kwietnia & Nowa Cerkiew & $\begin{array}{l}\text { Lignowy Szla- } \\
\text { checkie } \\
\text { Szprudowo }\end{array}$ & Protokół dla Nowej Cerkwi: zob. 13 kwietnia \\
\hline 13 kwietnia & Pączewo & $\begin{array}{l}\text { Nowa Cerkiew } \\
\text { Grabowo }\end{array}$ & Protokół dla Pączewa: zob.14 kwietnia \\
\hline 14 kwietnia & Skórcz & $\begin{array}{l}\text { Pączewo } \\
\text { Czarnylas } \\
\text { Skórcz }\end{array}$ & - \\
\hline 15 kwietnia & Barłożno & $\begin{array}{l}\text { Kościelna Jania } \\
\text { Barłożno }\end{array}$ & - \\
\hline 16 kwietnia & - & $\begin{array}{l}\text { Królówlas } \\
\text { Dzierżążno }\end{array}$ & - \\
\hline 17 kwietnia & Gniew & $\begin{array}{c}\text { Gniew } \\
\text { Walichnowy }\end{array}$ & - \\
\hline 18 kwietnia & Piaseczno & Piaseczno & - \\
\hline 19 kwietnia & - & $\begin{array}{l}\text { Tymawa } \\
\text { Opalenie }\end{array}$ & - \\
\hline
\end{tabular}


Podróz wizytacyjna archidiakona Andrzeja Albinowskiego w archidiakonacie pomorskim...

\begin{tabular}{|c|c|c|c|}
\hline 21 kwietnia & $\begin{array}{l}\text { Pieniążkowo } \\
\text { Lalkowy }\end{array}$ & $\begin{array}{l}\text { Pieniążkowo } \\
\text { Lalkowy }\end{array}$ & - \\
\hline 22 kwietnia & Nowe & Nowe & - \\
\hline 23 kwietnia & Komorsk Wielki & $\begin{array}{c}\text { Płochocin } \\
\text { Komorsk Wielki }\end{array}$ & - \\
\hline 24 kwietnia & - & Lubień Wielki & $\begin{array}{l}\text { Dekret dla Lubienia Wielkiego wystawiono } 25 \text { kwiet- } \\
\text { nia, jednak wizytator był w tej parafii zapewne już } \\
24 \text { kwietnia, kiedy pisano protokół }\end{array}$ \\
\hline 25 kwietnia & Lubień Wielki & $\begin{array}{l}\text { Bzowo } \\
\text { Jeżewo }\end{array}$ & $\begin{array}{l}\text { Dekret dla Jeżewa wystawiono } 26 \text { kwietnia, jednak } \\
\text { wizytator był w tej parafii zapewne już } 25 \text { kwietnia, } \\
\text { kiedy pisano protokół }\end{array}$ \\
\hline 26 kwietnia & Jeżewo & $\begin{array}{l}\text { Święte } \\
\text { Sartowice } \\
\text { Świecie }\end{array}$ & $\begin{array}{l}\text { Dekret dla Świecia wystawiono } 27 \text { kwietnia, jednak } \\
\text { wizytator był w tej parafii zapewne już } 26 \text { kwietnia, } \\
\text { kiedy pisano protokół. Protokół dla Sartowic jest } \\
\text { niedatowany, ale wpisany między protokołem dla } \\
\text { Świętego i Świecia }\end{array}$ \\
\hline 27 kwietnia & Świecie & Gruczno & $\begin{array}{l}\text { Dekret dla Gruczna wystawiono } 28 \text { kwietnia, jednak } \\
\text { wizytator był w tej parafii zapewne już } 27 \text { kwietnia, } \\
\text { kiedy pisano protokół }\end{array}$ \\
\hline 28 kwietnia & Gruczno & $\begin{array}{c}\text { Łąki Polskie } \\
\text { Przysiersk }\end{array}$ & $\begin{array}{l}\text { Dekret dla Przysierska wystawiono } 29 \text { kwietnia, jed- } \\
\text { nak wizytator był w tej parafii zapewne już } 28 \text { kwiet- } \\
\text { nia, kiedy pisano protokół }\end{array}$ \\
\hline 29 kwietnia & $\begin{array}{l}\text { Przysiersk } \\
\text { Drzycim }\end{array}$ & $\begin{array}{l}\text { Drzycim } \\
\text { Osie }\end{array}$ & $\begin{array}{l}\text { Dekret dla Osia wystawiono } 30 \text { kwietnia, jednak } \\
\text { wizytator był w tej parafii zapewne już } 29 \text { kwietnia, } \\
\text { kiedy pisano protokół }\end{array}$ \\
\hline 30 kwietnia & $\begin{array}{l}\text { Osie } \\
\text { Śliwice } \\
\text { Cekcyn } \\
\text { Bysław }\end{array}$ & $\begin{array}{l}\text { Śliwice } \\
\text { Cekcyn }\end{array}$ & Protokół dla Bysławia: zob. 1 maja \\
\hline 1 maja & Lubiewo & $\begin{array}{c}\text { Bysław } \\
\text { Lubiewo }\end{array}$ & - \\
\hline 2 maja & $\begin{array}{l}\text { Świekatowo } \\
\text { Serock }\end{array}$ & $\begin{array}{l}\text { Świekatowo } \\
\text { Serock }\end{array}$ & - \\
\hline 3 maja & Niewieścin & $\begin{array}{l}\text { Niewieścin } \\
\text { Topolno }\end{array}$ & $\begin{array}{l}\text { Dekret dla Topolna wystawiono } 4 \text { maja, jednak wi- } \\
\text { zytator był w tej parafii zapewne już } 3 \text { maja, kiedy } \\
\text { pisano protokół }\end{array}$ \\
\hline 4 maja & Topolno & - & - \\
\hline
\end{tabular}

początku nie można mieć pewności, w której parafii dekanatu puckiego rozpoczął swoją marszrutę. Najprawdopodobniej było to Oksywie, na co wskazywałaby datacja dekretu. Porównanie dat dekretów i protokołów, począwszy od Wejherowa, wskazuje najpewniej, że wizytator wyprzedził sekretarza. Z taką sytuacją mamy do czynienia zasadniczo do końca wizytacji świątyń w dekanacie puckim, a potem także w gdańskim ${ }^{15}$. Dopiero 27 marca w Godziszewie wystawiono zarówno protokół, jak i dekret. Tego samego dnia spisano jeszcze dekrety dla Giemlic, Skarszew i Wysina. Nie jest jednak pewne, czy datacja jest prawidłowa. Wydaje się raczej niemożliwe, by wizytator był w stanie odwiedzić jednego dnia tak odległe parafie $^{16}$.

Dnia 30 marca 1687 r. przypadała Wielkanoc. Analiza datacji dekretów może wskazywać, że archidiakon Albinowski spędzał ją

15 Tylko dla Gdańska protokół ma datę wcześniejszą niż dekret. 16 Giemlice i Wysin dzieli w linii prostej niemal $40 \mathrm{~km}$, a przez Skarszewy - nawet ponad $41 \mathrm{~km}$. Być może źle datowane są dekrety dla Godziszewa i Giemlic, skoro dla poprzedzających je Trąbek zalecenia powizytacyjne wystawiono już 24 marca. 


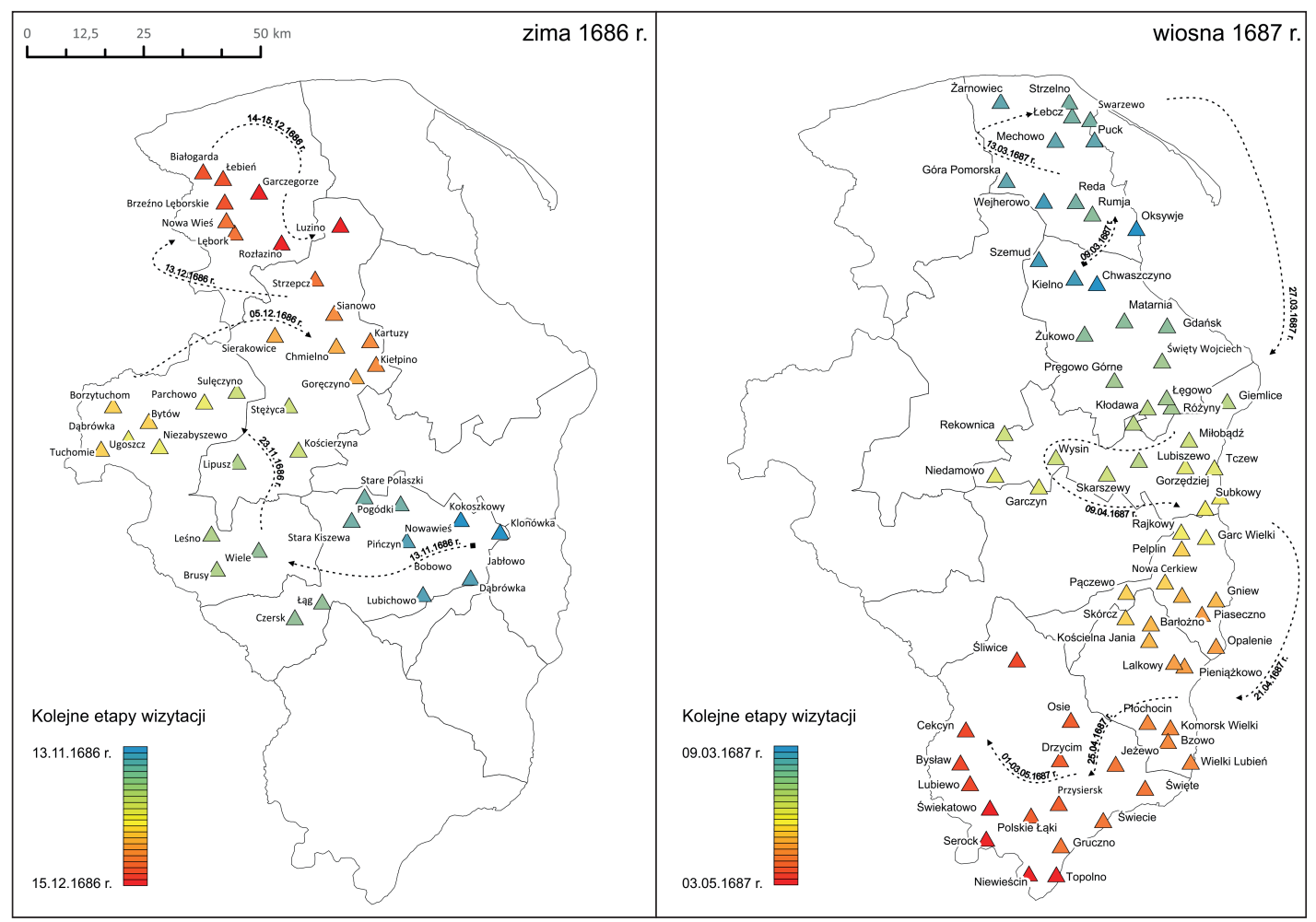

Mapa 1. Uproszczony schemat podróży wizytacyjnej po archidiakonacie pomorskim zimą 1686 i wiosną 1687 r.

Źródło: Tab. 1 i 2. B. Szady, „Religie i wyznania w Koronie w II połowie XVIII w.” (http:// atlasfontium.pll, dostęp: 29 września 2015). Oprac. kart. T. Związek

w Skarszewach ${ }^{17}$. I tu jednak nie ma pewności, gdyż równie dobrze mógł udać się np. do Miłobądza $^{18}$. Z kolei od wizytacji parafii rekownickiej (3 kwietnia) do końca podróży (4 maja) marszruta archidiakona jest dość łatwa do odtworzenia. Problem pojawia się tylko przy wizytacji wspomnianej wyżej parafii $\mathrm{Mi}$ łobądz. Wystawiony tam wspólny dekret dla Miłobądza, Subków, Dalwina i Gorzędzieja nosi datę 9 kwietnia. Tego samego dnia spisano też protokoły dla Gorzędzieja, Subków i Rajkowych. Czy rzeczywiście wizytator był

17 Za takim rozwiązaniem przemawiałoby znaczenie tej parafii jako jednego z najlepiej uposażonych pomorskich beneficjów. W XVIII w. archidiakonami pomorskimi byli często prepozyci skarszewscy: Jan Kazimierz Jugowski (prepozyt już w czasie wizytacji w 1687 r., archidiakon od 1705), Franciszek Józef Wybicki (prepozyt od 1736 r., archidiakon od 1764) czy też Bazyli Złocki (prepozyt i archidiakon od 1765 r.). Por. T. Nowicki, Stownik biograficzny rządców parafii archidiakonatu pomorskiego w XVII w., Lublin 2004, s. 93-94, 232, 238. wtedy we wszystkich wymienionych miejscowościach ${ }^{19}$ Kolejne wątpliwości może budzić droga przebyta 30 kwietnia. Źródło informuje, że spisano wówczas dekrety w Osiu, Śliwicach, Cekcynie i Bysławiu. Osie i Bysław, jeśli liczyć odległości według podanej w źródle kolejności wizytowania, dzieli od siebie ponad $40 \mathrm{~km}$ w linii prostej.

Powyższe wątpliwości związane $\mathrm{z}$ datacją i przeniesieniem jej na mapę skłaniają, by w dalszych analizach podróży wizytacyjnej z 1686 i 1687 r. brać pod uwagę datację pro-

\footnotetext{
18 Na taki wybór może wskazywać fakt, że po świętach, 1 kwietnia w Mitobądzu spisano protokół. Prawdopodobnie był tam wówczas obecny wizytator, bo dekret wystawiono dopiero 9 kwietnia. Zob. ADPel, G20a, k. 69, 172v; G20b, k. 42, 106. Jeśli tak było, to jadąc do Rekownicy, w której dekret i protokół wystawiono 3 kwietnia, mógtby ponownie przejeżdżać przez Skarszewy i Wysin. ADPel, G20a, k. 73, 170v; G20b, k. $44,104$.

19 Nie jest to nierealne, ale musiałby wówczas przebyć ponad $31 \mathrm{~km}$.
} 
tokołów, modyfikując ją na podstawie dat dekretów tylko na początku jesiennego i wiosennego etapu wizytacji. Po pierwsze, daty te umieszczano niemal przy każdej odwiedzanej świątyni, także filialnej czy kaplicy publicznej (jeśli tylko miały osobny opis). W konsekwencji przełożenie danych chronologicznych na mape pokazuje, że zasadniczo podróż odtworzona na tej podstawie była realna i wykonalna. Trzeba jednak pamiętać, że z pewnością nie oddaje ona dokładnej drogi samego wizytatora, choć niewątpliwie odzwierciedla ją w znacznej części.

\section{Etapy podróży}

Prezentowane wyżej zestawienia chronologiczne pokazują, że wizytację zarządzoną przez biskupa Bonawenturę Madalińskiego przeprowadzono w dwóch etapach. W czasie pierw- szego, który rozpoczął się w środę 13 listopada i zakończył w niedzielę 15 grudnia 1686 r., wizytator odwiedził kościoły w dekanatach: starogardzkim, mirachowskim, bytowskim i lęborskim. Drugi trwał od niedzieli 9 marca do poniedziałku 4 maja 1687 r. ${ }^{20}$ i objął dekanaty: pucki, gdański, tczewski, gniewski, nowski i świecki. Tabela 3, podzielona według dekanatów, przedstawia liczbę odwiedzonych miejscowości wraz z odpowiadającym im czasem trwania wizytacji.

Należy też zauważyć, że pierwsza jesienna podróż archidiakona Albinowskiego w zasadzie miała charakter ciągły. Analiza datacji nie wykazuje, by były w niej jakieś przestoje. Zasadniczo każdego dnia wizytator podejmował trud drogi. Pewne wątpliwości budzić może datacja protokołu dla Klonówki, o czym

Tab. 3. Czas wizytacji i liczba opisanych świątyń w poszczególnych dekanatach na podstawie dat protokotów i dekretów

\begin{tabular}{|c|c|c|}
\hline Dekanat & Dni wizytacji & $\begin{array}{l}\text { Liczba opisanych } \\
\text { świątyń }\end{array}$ \\
\hline Starogardzki & 13-22 listopada & 15 \\
\hline Mirachowski & $\begin{array}{l}23,26-28 \text { listopada } \\
5-10,15 \text { grudnia }\end{array}$ & 12 \\
\hline Bytowski & $\begin{array}{l}\text { 24-25, } 30 \text { listopada } \\
\text { 1-4 grudnia }\end{array}$ & 10 \\
\hline Lęborski & 12-14 grudnia & 7 \\
\hline 1 tura & 13 listopada-15 grudnia $1686 \mathrm{r}$. & 44 \\
\hline Pucki & 9-19 marca & 21 \\
\hline Gdański & 20-26 marca & 11 \\
\hline Tczewski & $\begin{array}{l}26-28 \text { marca } \\
1-9 \text { kwietnia }\end{array}$ & 17 \\
\hline Gniewski i nowski & 9-25 kwietnia & 26 \\
\hline Świecki & $\begin{array}{l}\text { 25-30 kwietnia } \\
\text { 1-4 maja }\end{array}$ & 17 \\
\hline 2 tura & 9 marca-4 maja 1687 r. & 92 \\
\hline \multicolumn{2}{|c|}{ Cała wizytacja } & 136 \\
\hline
\end{tabular}

20 W pierwszej turze wizytacji najwcześniejszy protokół (dla Starogardu) datowany jest na 15 listopada 1686 r., zaś najwcześniejszy dekret wydano 13 listopada (dla Klonówki). Ten etap kończyła wizytacja Luzina, w którym zarówno protokół, jak i dekret datowano na 15 grudnia. Z kolei tura wiosenna zaczęła się 9 marca 1687 r. Tego dnia datowano dekret dla Oksywia oraz protokół i dekret dla Chwaszczyna. Wizytacja zakończyła się 4 maja, bo wówczas wystawiono w Topolnie dekret, jednak, jak sugeruje datacja protokołu, wizytator był tam już 3 maja. 
wspomniano już wcześniej ${ }^{21}$. Brak też jakiejkolwiek informacji, gdzie wizytator przebywał w dniach 27 listopada $^{22}$ i 11 grudnia ${ }^{23}$.

W czasie wiosennego etapu wizytacji Albinowski przerwał swoją podróż z powodu przypadających na 30 marca 1687 r. Świąt Wielkanocnych. Jak już wspomniano, trudno jednoznacznie określić, w której miejscowości faktycznie spędzał święta. Z kolei 21 marca $^{24}$ i 20 kwietnia $^{25}$ nie wystawiono żadnego dekretu ani nie spisano protokołu, ale $\mathrm{z}$ pewnością nie przerwano wówczas wizytacji, o czym świadczą kolejne daty.

Dni, w których przeprowadzano wizytację w poszczególnych świątyniach, pokazują, że delegaci biskupa raczej sztywno trzymali się dekanatów i w znakomitej większości przypadków rozpoczynali wizytację kolejnego okręgu dopiero po odwiedzeniu wszystkich parafii $\mathrm{w}$ poprzednim. Bez wątpienia o wybraniu świątyni w kolejnym dekanacie, po zwizytowaniu części innego, decydowało kryterium geograficzne. $Z$ analizy datacji i odzwierciedlenia podróży na mapie wynika, że odstąpiono od tej zasady dwukrotnie.

W cyklu jesiennym na przemian z dekanatami bytowskim i lęborskim (choć tutaj odwiedzono w cyklu ciągłym wszystkie świątynie) wizytowano dość rozległy mirachowski. Mimo że nie była to największa jednostka kościelna tego typu $\mathrm{w}$ archidiakonacie ${ }^{26}$, to jednak z racji południkowego ułożenia i znacznych odległo-

21 Zob. przyp. 13.

22 We wtorek 26 listopada był w Kościerzynie, na co wskazuje datacja zarówno protokołu, jak i dekretu. ADPel, G20a, k. 17v, 152; G20b, k. 10, 91v. Być może zatrzymał się tutaj dzień dłużej, by dopiero 28 listopada pojawić się w oddalonej $010 \mathrm{~km}$ Stężycy.

23 W Strzepczu był na pewno 10 grudnia, na co wskazują daty protokołu i dekretu. ADPel, G20a, k. 22v, 153v; G20b, k. 14, 93. Możliwe, że 11 grudnia dotart już do Lęborka (ponad $20 \mathrm{~km}$ w linii prostej), ale czynności wizytacyjne podjął następnego dnia. ADPel, G20a, k. 34, 154v; G20b, k. 20, 94.

24 Analiza datacji może wskazywać, że delegaci biskupi byli w Gdańsku 20-22 marca. 20 marca spisano bowiem protokół, a 22 wystawiono dekret. ADPel, G20a, k. 56, 165v; G20b, k. 33v, 101.

2519 kwietnia spisano protokół dla Tymawy i Opalenia. ADPel, G20a, 97, 102v; G20b, k. 60v, 63. Być może w niedzielę 20 kwietnia wizytator odpoczywał w Pieniążkowie, a czynności wizytacyjne wykonywał dzień później. ADPel, G20a, k. 103, 181; G20b, k. 64, 111.

26 Zob. T. Nowicki, Liczba i sieć, s. 183. Por.: S. Litak, Kościót taciński, s. 124; tenże, Atlas Kościoła, s. 91 ści między poszczególnymi parafiami ${ }^{27}$ kościoty do niej należące wizytowano na raty.

$\mathrm{Z}$ kolei $\mathrm{w}$ cyklu wiosennym wizytatorzy połączyli odwiedziny w świątyniach leżących w dekanatach gniewskim i nowskim. Powodem była na pewno dość gęsta sieć świątyń katolickich na tym terenie. Wizytowanie miejscowości zlokalizowanych bardzo blisko siebie, niezależnie od przynależności dekanalnej, było dyktowane z pewnością racjonalnością wyboru i ekonomią czasu podróży. Wyraźnie widać to na załączonych mapach.

Można zatem przypuszczać, że celem wizytatorów było odwiedzanie po kolei parafii jednego dekanatu. Czasami tylko względy geograficzne zmuszały do odejścia od tego założenia i nietrzymania się sztywno świątyń o jednej przynależności dekanalnej.

\section{Analiza chronologiczno-geograficzna podróży}

Po ustaleniu poszczególnych etapów wizytacji i kolejności odwiedzanych miejscowości można przejść do przeanalizowania przebytej drogi. Przedmiotem tego badania może być $\mathrm{z}$ jednej strony liczba przejechanych kilometrów, z drugiej zaś czas poświęcony na wizytację. Na wstępie trzeba jednak podkreślić, że precyzyjne ustalenie rzeczywiście pokonanych odległości nie jest możliwe chociażby $\mathrm{z}$ tego powodu, że źródło nie informuje o dokładnej trasie podróży. Ponadto nie wiadomo, czy dzisiejsza sieć lokalnych dróg odpowiada tej sprzed ponad 300 lat. Dlatego też odcinki między kościołami w odwiedzanych miejscowościach należy liczyć w uproszczony sposób, a mianowicie w linii prostej. W takim wypadku - co należy mieć na uwadze - obliczone odległości są z pewnością zaniżone w stosunku do rzeczywiście przebytych.

Przechodząc do szczegółowej analizy podróży wizytatora, warto na początku ustalić, jakie pokonał dystanse ${ }^{28}$. Jak już stwierdzo-

\footnotetext{
27 Położone najdalej na północ Luzino znajdowało się ponad $70 \mathrm{~km}$ od zlokalizowanego w południowej części dekanatu Wiela.

28 W ustaleniach odległości w linii prostej posłużono się aplikacją internetową Google Earth. Przebyte przez wizytujących dystanse starano się obliczyć, zaznaczając dokładne położenie świątyń w poszczególnych miejscowościach.
} 
no, jesienny etap wizytacji rozpoczął się najpewniej w Klonówce, a zakończył w Luzinie. Wizytator musiał zatem przebyć co najmniej $413 \mathrm{~km}$. Ta część wizytacji trwała $32 \mathrm{dni}$, co oznacza, że średnio przemieszczał się w tempie niemal $13 \mathrm{~km}$ dziennie. Z kolei wiosenna marszruta rozpoczęła się w Oksywiu, a zakończyła w Topolnie - łącznie $715 \mathrm{~km}$ w ciągu 56 dni. Średnie dzienne tempo wynosiło zatem również niecałe $13 \mathrm{~km}$. Oczywiście wizytator nie przemieszczał się codziennie. Biorąc pod uwagę tylko dni wyszczególnione w tabelach 2 i 3, tzn. w czasie których wystawiano protokoły, liczba ich zmaleje do 76. Ponadto dystanse bywały różne. Zagadnienie to systematyzuje tabela 4. dzał wtedy najczęściej świątynie filialne lub miejscowości, w których dawniej znajdował się kościół lub kaplica katolicka ${ }^{29}$. W tych wsiach zapewne nie zatrzymywał się na długo. Nawet jeśli świątynia nadal istniała (jak np. w Bolszewie), to prawdopodobnie nie było możliwości przeprowadzenia szczegółowej wizytacji. Informacje mógł za to czerpać od miejscowych plebanów. Można w tym miejscu postawić pytanie, ile miejscowości mógł przeciętnie odwiedzić wizytujący w ciągu jednego dnia. Warto rozpatrzyć to zagadnienie przez pryzmat dekanatów, co obrazuje tabela 5.

Pierwsza część wizytacji objęła mniej świątyń i trwała krócej niż część druga, w której wizytowano również więcej miejscowości. Po-

Tab. 4. Odlegtości pokonywane przez wizytatora w ciągu jednego dnia i liczba odwiedzonych miejscowości ${ }^{30}$

\begin{tabular}{|c|c|c|c|c|c|c|}
\hline \multirow{2}{*}{ Dzienny dystans } & \multirow{2}{*}{ Liczba dni } & \multirow{2}{*}{$\%$} & \multicolumn{4}{|c|}{ Liczba dni, w których odwiedzono } \\
\cline { 4 - 7 } & & & 1 miejscowość & 2 miejscowości & 3 miejscowości & 4 miejscowości \\
\hline Do $10 \mathrm{~km}$ & 25 & 32,9 & 19 & 6 & - & - \\
\hline $11-20 \mathrm{~km}$ & 39 & 51,3 & 12 & 18 & 7 & 2 \\
\hline $21-30 \mathrm{~km}$ & 9 & 11,8 & 3 & 2 & 4 & - \\
\hline Powyżej $30 \mathrm{~km}$ & 3 & 3,9 & 1 & 1 & - & 1 \\
\hline Ogółem & $\mathbf{7 6}$ & $\mathbf{1 0 0 , 0}$ & $\mathbf{3 5}$ & $\mathbf{2 7}$ & $\mathbf{1 1}$ & $\mathbf{3}$ \\
\hline
\end{tabular}

Tabela pokazuje, że w ciągu jednego dnia wizytator pokonywał najczęściej do $20 \mathrm{~km}$ (84\% przypadków). Zwykle odwiedzał w takim czasie jedną parafię (46\%), czasami dwie (36\%). Oczywiście zdarzały się i takie dni, w których wizytował więcej świątyń, ale były to przypadki zdecydowanie rzadsze. W dniach, w których wizytator objechał trzy miejscowości, przebyta odległość nie była większa niż $30 \mathrm{~km}$. Trzykrotnie zdarzało się, że w ciągu 24 godzin złożył wizytę w czterech, ale odwie-

\footnotetext{
2913 grudnia zwizytowano cztery świątynie w dekanacie lęborskim: Nową Wieś, Garczegorze, Białogardę i Łebień. Odlegtość między nimi w linii prostej wynosi nieco ponad $18 \mathrm{~km}$. Z kolei 13 marca wizytator wyjechał najpewniej z Wejherowa, oglądając po drodze dawny kośció katolicki w Bolszewie, potem wizytując świątynię w Górze Pomorskiej, a następnie przez Kniewo, gdzie informował o nieistniejącej już kaplicy, dotarł do kaplicy w Lubocinie, odzyskanej niedawno przez biskupa Madalińskiego. Tego dnia także pokonał ponad $18 \mathrm{~km}$. Najdłuższa jednodniową drogę do czterech miejscowości odbył 24 marca, kiedy
}

nadto w trakcie podróży wiosennej przeciętnie odwiedzano każdego dnia więcej obiektów kościelnych niż jesienią. Najważniejszą przyczyną tej różnicy było na pewno większe zagęszczenie sieci parafialnej w pasach nadmorskim i nadwiślańskim niż na terenach położonych w środkowej i zachodniej części archidiakonatu. Jeśli spojrzeć na tę kwestię przez pryzmat dekanatów, to okazuje się, że przeciętnie najwięcej świątyń w najkrótszym czasie archidiakon Albinowski zwizytował

to jadąc z Żukowa, opisał kościoły i kaplice w Pręgowie, Czapielsku, Mierzeszynie i Wielkiej Żuławie, pokonując ponad $32 \mathrm{~km}$.

30 Przy obliczaniu odlegtości przyjęto zasadę, że do drogi przebytej w danym dniu doliczano odległość od świątyni wizytowanej w dniu poprzednim. W liczbie dni pominięto te, w których rozpoczynano wizytację, oraz te, dla których brak informacji o pisaniu protokołów wizytacyjnych. Stąd też liczba dni związanych z podróżą jest mniejsza od wykazanej w tabeli 3 sumy dni wizytacji. 
Tab. 5. Średnia liczba świątyń wizytowanych w poszczególnych dekanatach w ciągu jednego dnia

\begin{tabular}{|c|c|c|c|}
\hline Dekanat & Liczba opisanych świątyń & Liczba dni ${ }^{1}$ & $\begin{array}{c}\text { Średnia liczba świątyń } \\
\text { wizytowanych jednego dnia }\end{array}$ \\
\hline Starogardzki & 15 & 7 & 2,1 \\
\hline Mirachowski & 12 & 10 & 1,2 \\
\hline Bytowski & 10 & 7 & 1,4 \\
\hline Lęborski & 7 & 3 & 2.3 \\
\hline 1 tura & $\mathbf{4 4}$ & $\mathbf{2 7}$ & $\mathbf{1 , 6}$ \\
\hline Pucki & 21 & 10 & 2,1 \\
\hline Gdański & 11 & 6 & 1,8 \\
\hline Tczewski & 17 & 10 & 1,7 \\
\hline Gniewski i nowski & 26 & 15 & 1,7 \\
\hline Świecki & 17 & 8 & 2,1 \\
\hline 2 tura & $\mathbf{9 2}$ & $\mathbf{4 9}$ & $\mathbf{1 , 9}$ \\
\hline Cała wizytacja & $\mathbf{1 3 6}$ & $\mathbf{7 6}$ & $\mathbf{1 , 8}$ \\
\hline
\end{tabular}

1 Dni, w których datowano protokoły wizytacyjne.

$2 \mathrm{~W}$ obu dekanatach parafie wizytowano na przemian, czasami tego samego dnia.

w lęborskim ${ }^{31}$. Trzeba jednak pamiętać, że był to okręg kościelny, w którym wszystkie świątynie podlegały prepozytowi z Lęborka, a ponadto duszpasterstwo było ograniczone do niewielkiej liczby katolików. Szybko uporał się z dekanatem świeckim, co było o tyle zaskakujące, że był to największy dekanat $\mathrm{w}$ archidiakonacie ${ }^{32}$. W podobnym tempie wizytował rozległy dekanat starogardzki ${ }^{33}$ oraz stosunkowo lepiej nasycony świątyniami puc$\mathrm{ki}^{34}$. W kolejnych dekanatach przeprowadzano wizytację wolniej. Są tutaj okręgi kościelne o relatywnie rzadkiej sieci świątyń (Bytów,

31 Mimo że przeciętnie jedna świątynia katolicka przypadała tutaj na aż 179 km². Zob. T. Nowicki, Liczba i sieć, s. 183.

$320 \mathrm{k} .1710 \mathrm{r}$. jeden obiekt sakralny przypadał tutaj przeciętnie na ok. $82 \mathrm{~km}^{2}$. Nie była to wprawdzie wartość najwyższa, bo rzadszą sieć świątyń miały dekanaty lęborski, bytowski, mirachowski czy nawet starogardzki, lecz wizytator poświęcił relatywnie mało czasu na odwiedzenie i opisanie kościołów dekanatu świeckiego. Zob. tamże. Być może dość szybka podróż wiązała się z aspektem psychologicznym po prostu wizytacja zmierzała już ku końcowi. Możliwe, że powód ten w podśsiadomy sposób wpłynął na działania wizytatora.

$330 k .1710$ r. jeden obiekt sakralny w dekanacie starogardzkim przypadał średnio na ok. $89 \mathrm{~km}^{2}$. Zob. tamże.

34 Jeden taciński obiekt sakralny przypadat tutaj na ok. $61 \mathrm{~km}^{2}$. Zob. tamże.
Mirachowo) $)^{35}$, jak też o dość zwartej (Gdańsk, Tczew, Gniew i Nowe) ${ }^{36}$.

Jak już wcześniej zaznaczono, wyliczone przeciętne nie oddają faktycznie przebytych odległości. Biorąc pod uwagę, że w poszczególnych dekanatach były obszary o zróżnicowanym zgęszczeniu osadnictwa ${ }^{37}$, warto ustalić średni dystans, jaki wizytator pokonywał jednego dnia, oraz obliczyć przeciętne odległości między odwiedzanymi miejscowościami.

Przeciętnie dystans pokonywany jednego dnia wynosił ok. $15 \mathrm{~km}$. Oczywiście odległość ta zależna była z jednej strony od zagęszczenia odwiedzanych obiektów sakralnych w wizytowanym dekanacie, z drugiej zaś od

35 W dekanacie bytowskim jedna świątynia przypadała średnio na ok. $107 \mathrm{~km}^{2}$, zaś w mirachowskim - na ok. 88 km². Zob. tamże.

36 Gęstość sieci kościelnej wynosiła odpowiednio: w dekanacie gdańskim - $42 \mathrm{~km}^{2}$, w tczewskim - $51 \mathrm{~km}^{2}$, w nowskim - $51 \mathrm{~km}^{2}$, zaś w gniewskim - najmniej, bo $26 \mathrm{~km}^{2}$. Zob. tamże.

37 Por.: M. Biskup, M. Tomczak, Mapy województwa pomorskiego w drugiej połowie XVI wieku, Toruń 1955 (mapa sieci parafialnej na końcu opracowania); K. Mikulski, Osadnictwo wiejskie województwa pomorskiego od połowy XVI do końca XVII wieku, Toruń 1994 (mapy na końcu opracowania); Ziemie polskie Korony w XVI w. Przestrzenna baza danych, Instytut Historii PAN im. Tadeusza Manteuffla (http:// atlasfontium.pl/, dostęp: 2 kwietnia 2015). 
ilości odwiedzanych miejscowości i związanej z tym konieczności przeprowadzenia wizytacji. W każdym razie obliczona średnia pokazuje, że w czasie pierwszej, jesiennej tury wizytujący pokonywali dziennie przeciętnie 0,6 km więcej. Gdyby pomnożyć tę różnicę przez liczbę dni, w których wizytator przemieszczał się podczas drugiej, wiosennej tury, to okaże się, że byłoby to proporcjonalnie o niemal $30 \mathrm{~km}$ mniej. Rzecz jasna rozbieżności dotyczą poszczególnych dekanatów, co wyraźnie pokazuje tabela 6 . Trzeba zatem odpowiedzieć na jeszcze jedno pytanie, a mianowicie jaka odległość dzieliła w poszczególnych dekanatach opisywane miejscowości. Kwestie te obrazuje tabela 7.

Okazuje się, że odległości między wizytowanymi świątyniami w poszczególnych dekanatach wynosiły średnio ok. 8-9 km. Oczywiście w niektórych przypadkach były one większe lub mniejsze, a najbardziej zauważalna dotyczy dekanatu mirachowskiego, który z racji swojego

Tab. 6. Średni jednodniowy dystans pokonywany przez wizytującego w poszczególnych dekanatach

\begin{tabular}{|c|c|c|c|}
\hline Dekanat & Liczba przebytych kilometrów & Liczba dni' & Średnia dzienna w km \\
\hline Starogardzki & 116 & 7 & 16,6 \\
\hline Mirachowski & 152 & 10 & 15,2 \\
\hline Bytowski & 86 & 7 & 12,3 \\
\hline Lęborski & 59 & 3 & 19,7 \\
\hline 1 tura (jesień 1686 r.) & $\mathbf{4 1 3}$ & $\mathbf{2 7}$ & $\mathbf{1 5 , 3}$ \\
\hline Pucki & 150 & 10 & 15,0 \\
\hline Gdański & 93 & 6 & 15,5 \\
\hline Tczewski & 157 & 10 & 15,7 \\
\hline Gniewski i nowski ${ }^{2}$ & 159 & 15 & 10,6 \\
\hline Świecki & 156 & 8 & 19,5 \\
\hline 2 tura (wiosna 1687 r.) & $\mathbf{7 1 5}$ & $\mathbf{4 9}$ & $\mathbf{1 4 , 6}$ \\
\hline Cała wizytacja & $\mathbf{1 1 2 8}$ & $\mathbf{7 6}$ & $\mathbf{1 4 , 8}$ \\
\hline
\end{tabular}

${ }^{1}$ Dni, w których datowano protokoły wizytacyjne.

${ }^{2} \mathrm{~W}$ obu dekanatach parafie wizytowano na przemian, czasami tego samego dnia.

Tab. 7. Przeciętna odlegtość między wizytowanymi miejscowościami z podziatem na dekanaty

\begin{tabular}{|c|c|c|c|}
\hline Dekanat & Liczba przebytych kilometrów & $\begin{array}{c}\text { Liczba wizytowanych } \\
\text { obiektów }\end{array}$ & $\begin{array}{c}\text { Średni dystans między } \\
\text { obiektami w km }\end{array}$ \\
\hline Starogardzki & 116 & 15 & 7,7 \\
\hline Mirachowski & 152 & 12 & 12,7 \\
\hline Bytowski & 86 & 10 & 8,6 \\
\hline Lęborski & 59 & 7 & 8,4 \\
\hline 1 tura (jesień 1686 r.) & $\mathbf{4 1 3}$ & $\mathbf{4 4}$ & $\mathbf{9 , 4}$ \\
\hline Pucki & 150 & 21 & 7,1 \\
\hline Gdański & 93 & 11 & 8,5 \\
\hline Tczewski & 157 & 17 & 9,2 \\
\hline Gniewski i nowski & 159 & 26 & 6,1 \\
\hline Świecki & 156 & 17 & 9,2 \\
\hline 2 tura (wiosna 1687 r.) & $\mathbf{7 1 5}$ & $\mathbf{9 2}$ & $\mathbf{7 , 8}$ \\
\hline Cała wizytacja & $\mathbf{1 1 2 8}$ & $\mathbf{1 3 6}$ & $\mathbf{8 , 3}$ \\
\hline
\end{tabular}




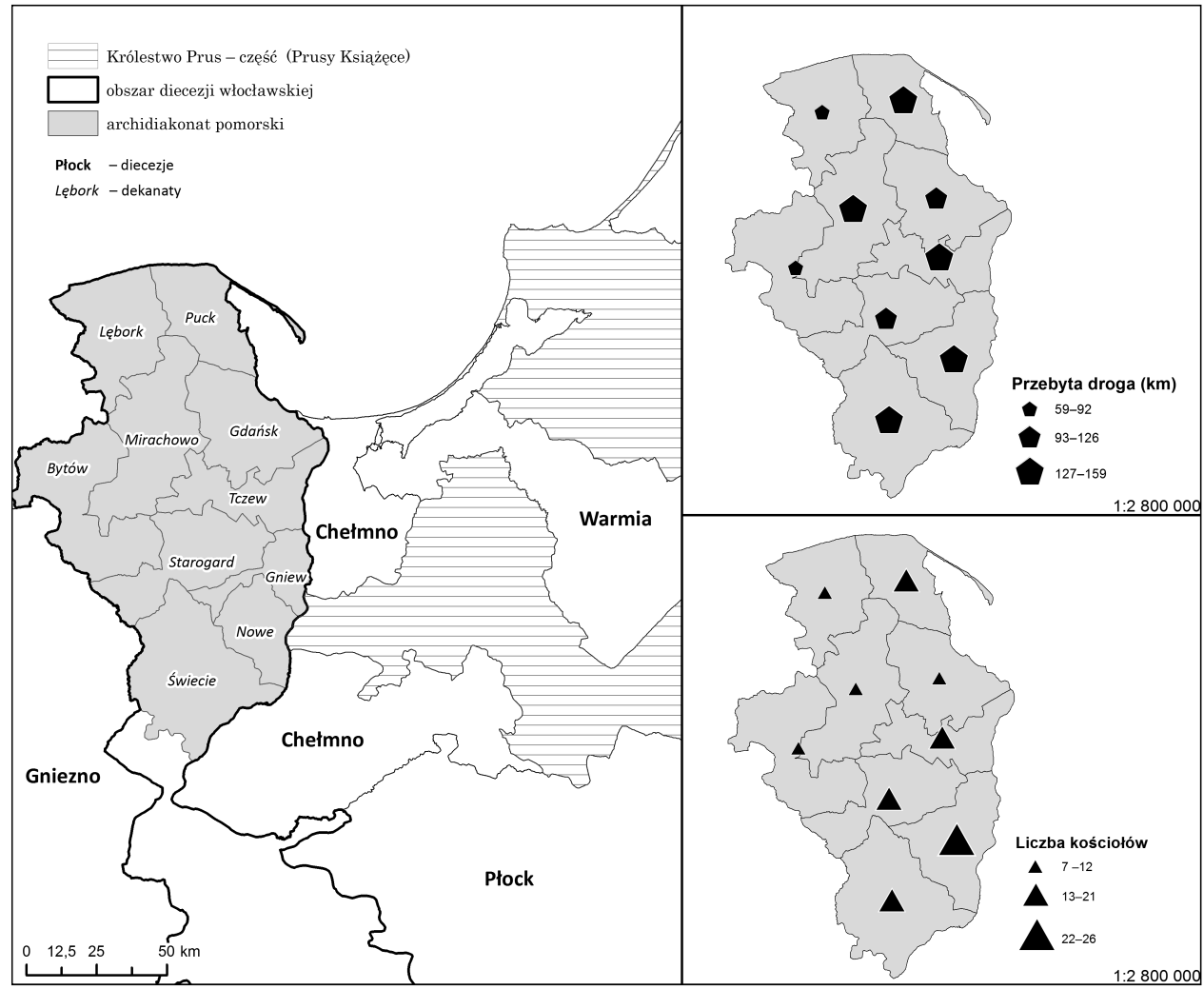

Mapa 2. Droga przebyta podczas wizytacji kanonicznej w kilometrach wraz z liczbą odwiedzonych kościotów parafialnych w poszczególnych dekanatach archidiakonatu pomorskiego w roku 1686 oraz 1687.

Źródto: Tab. 5. Podkład kart.: B. Szady, „Religie i wyznania w Koronie w II połowie XVIII w.” (http:// atlasfontium.pll, dostęp: 29 września 2015). Oprac. kart. T. Związek

południkowego położenia i powierzchni obejmującej ok. $1578 \mathrm{~km}^{2}$ wizytowany był w trzech turach. Średnie odległości, które pokonywał wizytator, zmierzając do zlokalizowanych w nim obiektów sakralnych, wynosiły niemal $13 \mathrm{~km}$. $\mathrm{Na}$ drugim biegunie są dekanaty gniewski i nowski - tam poszczególne kościoły znajdowały się najbliżej siebie: średnio nieco ponad $6 \mathrm{~km}$. Gdy spojrzeć na tabelę przez pryzmat jesiennej i wiosennej tury, potwierdza ona większe zagęszczenieświątyń w dekanatach nadwiślańskich i nadmorskich. Odbiega nieco od tego wizerunku dekanat tczewski, lecz w przeciwieństwie do ułożonego południkowo mirachowskiego rozciągał się raczej równoleżnikowo: od Wisły na wschodzie do wsi parafialnej Niedamowo na zachodzie. Granice zachodnie przebiegały zaś 5-6 km od Kościerzyny. Archidiakon Albi- nowski skontrolował po kolei wszystkie świątynie dekanatu, dlatego też przemierzył więcej kilometrów: średnio 9.

Patrząc na całość podróży wizytatorów biskupa Madalińskiego, nawet w oparciu o uproszczone wyliczenia bazujące na odległościach w linii prostej, można zauważyć dążenie do minimalizacji odległości i oszczędzenia czasu. Oczywiście ostateczne rezultaty oparte o sieć ówczesnych dróg i analizę ówczesnego środowiska geograficznego mogą zweryfikować to ustalenie, niemniej jednak prezentowane wyniki pokazują, że z jednej strony starano się wizytować parafie według ich bliskości geograficznej, z drugiej zaś dążono do wizytowania jednostek leżących w tym samym dekanacie. Odstępstwa od tej reguły były wynikiem dysonansu między przesłankami geograficznymi a administracyj-

\section{I24 Studia Geohistorica • Nr 03. 2015}


nymi. Tam, gdzie było to uzasadnione, delegat biskupa rezygnował z wizytowania świątyń tego samego dekanatu na rzecz odwiedzenia miejscowości leżącej bliżej, choć należącej już do innego okręgu dekanalnego. Dzięki temu miał do pokonania mniejsze odległości między kolejnymi miejscowościami, a jednocześnie jego podróż przebiegała sprawnie. Łącznie archidiakon Albinowski pokonał co najmniej $1128 \mathrm{~km}$. Jest to na pewno rezultat niższy od rzeczywistego, dlatego też w dalszych badaniach nad podró-

\section{Bibliografia}

\section{Źródła}

Archiwum Diecezjalne w Pelpinie, zespół Gedanensia

Visitatio Archidiaconatus Pomeraniae sub felicissimis auspiciis Illustrissimi et Reverendissimi Domini D. Bonaventurae de Niedielsko Madalinski Dei et Apostolicae Sedis gratia Episcopi Vladislaviensis et Pomeraniae a Perillustri et Admodum Reverendo Domino Andrea Albinowski Archidiacono Pomeraniae, Cantore Premisliensi, Praeposito Volboriensi Anno 1686 et 1687 peracta, sygn. G20a.

\section{Opracowania}

Biskup M., Tomczak M., Mapy województwa pomorskiego $w$ drugiej potowie XVI wieku, Toruń 1955.

Chodyński S., Biskupi sufragani wtoctawscy, Włocławek 1906.

Główka D., Akta wizytacji kościelnych z XVIIXVIII wieku jako źródto do historii kultury materialnej: gospodarstwo wiejskie $w$ dobrach parafialnych $w$ archidiakonacie warszawskim, w: Szkice z dziejów materialnego bytowania spoteczeństwa polskiego, red. M. Dembińska, Wrocław 1989, s. 233-254.

Kujawski W., Repertorium ksiag wizytacji kanonicznych biskupów kujawsko-pomorskich przechowywanych w Archiwum Diecezjalnym $w$ Pelplinie, „Archiwa, Biblioteki i Muzea Kościelne”, 84, 2005, s. 120-195.

Litak S., Akta wizytacyjne parafii z XVI-XVIII wieku jako źródto historyczne, „Zeszyty Naukowe KUL”, 5 (3), 1962, s. 41-58. żami wizytatorów warto podjąć próbę ustalenia faktycznie przebytej drogi. Wymaga to jednak szczegółowych badań nad siecią dróg w danym okresie i na danym terenie, a także uwzględnienia środowiska geograficznego wizytowanego obszaru. Możliwe jest również poszerzenie bazy źródłowej o inne wizytacje konkretnego okręgu kościelnego i podjęcie badań porównawczych. Takie studia powinny choćby dać odpowiedź, na ile późniejsi wizytatorzy czerpali z doświadczenia poprzedników.

Visitatio Archidiaconatus Pomeraniae sub felicissimis auspiciis Ilustrissimi et Reverendissimi Domini Bonaventurae de Niedzielsko Madalinski, Dei et Apostolicae Sedis Gratia Episcopi Vladislaviensis et Pomeraniae, a Perillustri et Admodum Reverendo Domino Andrea Albinowski Archidiacono Pomeraniae, Cantore Praemisliensi, Praeposito Volboriensi, Anno Domini 1686 et 1687 peracta, sygn. G20b.

Litak S., Atlas Kościota tacińskiego w Rzeczypospolitej Obojga Narodów w XVIII wieku, Lublin 2006.

Litak S., Kościót taciński w Rzeczypospolitej okoto 1772 roku, Lublin 1996.

Mikulski K., Osadnictwo wiejskie województwa pomorskiego od potowy XVI do końca XVII wieku, Toruń 1994.

Nowicki T., Liczba i sieć swiątyń $w$ archidiakonacie pomorskim w latach 1583-1781, „Studia Pelplińskie”, 28, 1999, s. 171-196.

Nowicki T., Ministri ecclesiae. Stużba kościelna $i$ witrycy $w$ diecezji wtoctawskiej $w$ XVIII wieku, Lublin 2011.

Nowicki T., Stownik biograficzny rzadców parafii archidiakonatu pomorskiego $w$ XVII $w$., Lublin 2004.

Olczak S., Wizytacje jako źródto do badań nad klerem parafialnym, „Summarium”, 8, 1979, s. 253-258. 
Olczak S., Źródta kościelne z końca XVI Ziemie polskie Korony w XVI w. Przestrzenna i pierwszej potowy XVII wieku do badań nad duchowieństwem, „Przegląd Tomistyczny”, 2, 1986, s. 275-291.

baza danych, Instytut Historii PAN im. Tadeusza Manteuffla (http://atlasfontium.pl/, dostęp: 2 kwietnia 2015).

Szady B., Geografia struktur religijnych i wyznaniowych $w$ Koronie $w$ II potowie XVIII wieku, Lublin 2010.

\section{Canonical Visitation Journey of Archdeacon Andrzej Albinowski in the Archdeanery of Pomerania in 1686 and 1687}

\section{Summary}

In late autumn 1686 and early spring 1687 the archdeacon of Pomerania Andrzej Albinowski, who represented the bishop of Kujawy and Pomerania - Bonawentura Madaliński - conducted a canonical visitation of the parishes composing the archdeanery of Pomerania. The source basis of the article consists of the dates of visitation activities recorded in the fair copy rewritten in the second half of the $18^{\text {th }} \mathrm{c}$. The present article reconstructs the route of the visitor and the stages of his journey. The sequence of the visited sacral places was set down and an attempt was made to establish the covered distances on the basis of a simplified method determining the distances covered by the visitor in a straight line based on the contemporary maps. The analysis of the source records characterized the journey of archdeacon Albinowski during the autumn and spring stages of his visitation with mean daily distan- ces covered by the visitor as well as the average number of visited churches during one day and the average distances between the visited places in particular deaneries. While analyzing the journey made by Rev. Albinowski, even by means of a simplified method of establishing the distance in a straight line, a clear tendency to minimize the distances and to economize time can be noticed. What can be observed at the same time are the efforts of the bishop's delegate to visit the churches on the basis of deaneries. Where, however, for geographical reasons it was not rational to visit the churches belonging to one deanery, this rule was given up and the nearest places, though situated in another deanery, were traveled to. It should be added that further studies on visitation journeys should undertake an attempt to establish the actually covered distance on the grounds of a broader source basis.

Słowa kluczowe : archidiakonat pomorski, diecezja włocławska, Bonawentura Madaliński, Andrzej Albinowski, podróże wizytacyjne, wizytacja kanoniczna, datacja wizytacji

Keywords: archdeanery of Pomerania, diocese of Włocławek, Bonawentura Madaliński, Andrzej Albinowski, visitation journeys, canonical visitation, visitation date

dr hab. Tomasz Nowicki - adiunkt w Katedrze Historii Ustroju i Administracji Polski w Instytucie Historii KUL (e-mail: tonowi@kul.pl) 